\title{
ANALISIS PENDAPATAN ASLI DAERAH (PAD) KABUPATEN JAYAPURA
}

\author{
Verdi Payung Tappi \\ *Dosen Prodi Ekonomi Pembangunan, STIE Port Numbay Jayapura
}

\begin{abstract}
The research objectives are 1) to determine the direct and indirect effect of hotel tax on local revenue through local taxes in Jayapura Regency; 2) to determine the magnitude of the direct and indirect effect of restaurant tax on local revenue through local taxes in Jayapura Regency. . The method used is quantitative method. The results show that 1) the effect of local taxes (Y2) on local revenue (Y3) is 1.05 with a significance level of 0.102 or greater than 0.05 which means that it is not significant meaning that there is a relationship between local taxes and local revenue but not significant, this is in line with the hypothesis in this study; 2) the indirect effect of each variable, where the effect of hotel tax (X1) on regional income (Y3) through local taxes (Y1) is 3.77, meaning that if the amount of hotel tax revenue increases, local revenue (Y2) also increases. Meanwhile, the effect of restaurant tax (X2) on local revenue (Y2) through local tax (Y1) is 2.90, meaning that if the restaurant tax (X2) increases, local original income (Y2) also increases; 3) The total effect is the overall effect between direct and indirect effects on each exogenous variable, namely hotel tax (X1), restaurant tax (X2) through local tax (Y1) on local revenue (Y2), to see the effect the total of each exogenous variable to each local tax function (Y1) and local revenue (Y2).
\end{abstract}

\section{Keywords: Hotel Tax, Restoren Tax, Regional Tax and Regional Original Income}

\begin{abstract}
Abstrak: Tujuan Penelitian yaitu 1) untuk mengetahui besarnya pengaruh langsung dan pengaruh tidak langsung pajak hotel terhadap pendapatan asli daerah melalui pajak daerah di Kabupaten Jayapura;2) untuk mengetahui besarnya pengaruh langsung dan pengaruh tidak langsung pajak restoran terhadap pendapatan asli daerah melalui pajak daerah di Kabupaten Jayapura. Metode yang digunakan yaitu metode kuantitatif. Hasil penelitian menunjukkan bahwa 1) pengaruh pajak daerah $\left(\mathrm{Y}_{2}\right)$ terhadap pendapatan asli daerah $\left(\mathrm{Y}_{3}\right)$ adalah 1,05 dengan tingkat signifikansi 0,102 atau lebih besar dari 0,05 yang berarti tidak signifikan artinya bahwa ada hubungan antara pajak daerah dengan pendapatan asli daerah tapi tidak signifikan, hal ini searah dengan hepotesis dalam penelitian ini; 2) pengaruh tidak langsung masing-masing variabel, dimana pengaruh pajak hotel $\left(\mathrm{X}_{1}\right)$ terhadap pendapatan alsi daerah $\left(\mathrm{Y}_{3}\right)$ melalui pajak daerah $\left(\mathrm{Y}_{1}\right)$ sebesar 3,77 artinya apabila jumlah penerimaan pajak hotel naik maka pendapatan asli daerah $\left(\mathrm{Y}_{2}\right)$ juga naik. Sedangkan pengaruh pajak restoran $\left(\mathrm{X}_{2}\right)$ terhadap pendapatan asli daerah $\left(\mathrm{Y}_{2}\right)$ melalui melalui pajak daerah $\left(\mathrm{Y}_{1}\right)$ sebesar 2,90 artinya apabila pajak restoran $\left(\mathrm{X}_{2}\right)$ naik maka pendapatan asli daerah $\left(\mathrm{Y}_{2}\right)$ juga mengalami kenaikan; 3) Pengaruh total adalah pengaruh secara keseluruhan antara pengaruh langsung dan pengaruh tidak langsung pada masing-masing variabel eksogen yaitu pajak hotel $\left(\mathrm{X}_{1}\right)$, pajak restoran $\left(\mathrm{X}_{2}\right)$ melalui pajak daerah $\left(\mathrm{Y}_{1}\right)$ terhadap pendapatan asli daerah $\left(\mathrm{Y}_{2}\right)$, untuk melihat pengaruh total masing-masing variabel eksogen terhadap masing-masing fungsi pajak daerah $\left(\mathrm{Y}_{1}\right)$ serta pendapatan asli daerah $\left(\mathrm{Y}_{2}\right)$.
\end{abstract}

Kata Kunci : Pajak Hotel, Pajak Restoren, Pajak Daerah dan Pendapatan Asli Daerah

\section{Latar Belakang}

Dengan berlakunya undang-undang Nomor 33 Tahun 2004 maka pemerintah daerah dituntut untuk lebih aktif dalam menggali sumber-sumber pendapatan daerah yang potensial yang dapat memberikan penambahan penerimaan daerah baik dari sektor pajak, sektor retribusi dan penerimaan lainnya yang dapat digunakan untuk membantu pemerintah dalam membiayai program-program daerah yang telah disusun dan direncanakan.

Pendapatan Asli Daerah (PAD) merupakan salah satu sumber penerimaan daerah dengan komposisi terdiri dari pajak daerah, retribusi daerah dan pendapatan lain-lain yang sah, selain bantuan dari pemerintah pusat, selama ini daerah menunjukkan presentase pendapatan asli daerahnya relatif masih kecil, pada umumnya anggaran pendapatan dan belanja daerah (APBD) suatu daerah masih didominasi oleh sumbangan dari pemerintah pusat dan sumbangansumbangan lain yang di atur dengan perundang undangan, hal ini sangat tergantung kepada pemerintah pusat sehingga kemampuan daerah untuk mengembangkan potensi yang mereka miliki menjadi sangat terbatas, rendahnya pendapatan asli daerah dari suatu daerah bukan disebabkan oleh minimnya sumber pendapatan asli daerah tetapi lebih disebabkan pada minimnya penggalian potensi masih sangat kurang karena daerah pada umumnya masih sangat tergantung pada bantuan dari pemerintah pusat.

Untuk dapat meningkatkan pendapatan asli daerah dari sumber-sumber pendapatan daerah yang ada baik itu pajak maupun retribusi daerah pemerintah harus meningkatkan kualitas sumber daya manusia yang dimilikinya terutama aparat perpajakan baik kualitas intelektualnya maupun kualitas moralnya untuk mampu menggali sumber-sumber pajak melalui cara intensifikasi maupun cara ekstensifikasi dengan menggali objek-objek pajak yang baru, lebih khususnya lagi dengan berlakunya Undang-undang Nomor 28 tahun 2009 yang memberikan peluang bagi daerah untuk menambah sumber penerimaan daerah dari Pajak Bumi dan Bangunan serta Pajak Perolehan Atas Tanah dan Bangunan, ini harus dimanfaatkan secara maksimal oleh pemerintah daerah untuk memungut sumber penerimaan daerah yang baru tersebut.

Pemerintah Daerah Kabupaten Jayapura merupakan kabupaten tertua di provinsi Papua yang notabene bagian integral dari Negara Kesatuan Republik Indonesia yang dalam pelaksanaan pembangunannya banyak mengalami peningkatan di berbagai sector, 
keberhasilan itu tentunya didukung oleh pemanfaatan keuangan yang ada secara optimal oleh pemerintah daerah serta bantuan pemerintah pusat dan juga tidak terlepas dari dukungan dan perolehan dari pajak daerah, dan retribusi daerah yang selama ini merupakan sumber keuangan penerimaan daerah di mana cukup memberikan andil yang besar dalam pembiayaan pembangunan daerah tersebut. Pemerintah daerah berupaya untuk mengoptimalkan pendapatan daerah dari berbagai sektor, diantaranya adalah sektor hasil pajak, hasil retribusi daerah, laba badan usaha perusahaan daerah dan lain-lain pendapatan yang sah serta Bagi Hasil Pajak (BHP) dan Bagi Hasil Bukan Pajak (BHBP). Sektor-sektor tersebut dianggap sebagai salah satu sumber pembiayaan daerah yang harus digali dan dikembangkan untuk membiayai kebutuhan daerah. Tanggung jawab memungut pajak dan retribusi tidak saja menjadi tanggung jawab pemerintah daerah semata tapi juga kesadaran dari setiap wajib pajak untuk menulasi semua kewajibannya, Dari pajak ini berbentuk media pungutan yang dibayarkan sesuai dengan nilai nominal yang terterah pada blangko penagihan pajak yang dibagikan kepada masyarakat, dan juga membuka hati masyarakat untuk taat membayar pajak, karena sumber pendapatan asli daerah yang berasal dari persentase pajak sangat tinggi jika dibanding dengan sumber yang lain.

Kabupaten Jayapura merupakan pintu gerbang bagi provinsi Papua melalui jalur udara dimana bandara Sentani berada dalam wilayah kabupaten Jayapura sehingga ini berdampak bagi iklim usaha perhotelan yang mempunyai prospek yang baik sehingga banyak investor yang membuka usaha perhotelan di Kabupaten Jayapura dan secara tidak langsung akan memberikan dampak bagi penerimaan pajak hotel serta pajak daerah di Kabupaten Jayapura akan meningkat, seiring meningkatnya pembangunan perhotelan mulai dari kelas melati sampai dengan hotel berbintang akan berpengaruh terhadap jumlah tamu yang menggunakan jasa perhotelan dan ini dibarengi dengan tingginya kebutuhan akan konsumsi bagi tamu-tamu hotel dan restoran atau rumah makan akan menjadi patner atau pasangan bagi pihak hotel untuk menyediakan konsumsi bagi setiap tamu-tamu yang menginap di masing-masing hotel dan ini merupakan peluang bagi pemerintah kabupaten Jayapura untuk menambah penerimaan dari sektor pajak restoran.

\section{Tujuan Penelitian}

1. Untuk mengetahui besarnya pengaruh langsung dan pengaruh tidak langsung pajak hotel terhadap pendapatan asli daerah melalui pajak daerah di Kabupaten Jayapura;

2. Untuk mengetahui besarnya pengaruh langsung dan pengaruh tidak langsung pajak restoran terhadap pendapatan asli daerah melalui pajak daerah di Kabupaten Jayapura.

\section{Tinjauan Pustaka}

Pengertian Pajak

Pajak adalah iuran rakyat kepada kas negara berdasarkan Undang-undang dengan tidak mendapat timbal balik secara langsung yang dapat ditunjukkan dan digunakan untuk membayar pengeluaran umum." Menurut Soemitro (2003) menyebutkan pajak merupakan sumber utama penerimaan negara yang bertujuan untuk meningkatkan kesejahteraan rakyat dengan cara meningkatkan pelayanan publik.

Berdasarkan Undang Undang Nomor 28 Tahun 2009, pajak adalah kontribusi wajib pajak kepada negara yang terutang oleh orang pribadi atau badan yang bersifat memaksa berdasarkan undang-undang, dengan tidak mendapatkan imbalan secara langsung dan digunakan untuk keperluan negara bagi sebesar-besarnya kemakmuran rakyat.

\section{Pengertian Pajak Daerah}

Menurut Undang-Undang Nomor 28 Tahun 2009, Pajak daerah, yang selanjutnya disebut Pajak, adalah kontribusi wajib kepada Daerah yang terutang oleh orang pribadi atau badan yang bersifat memaksa berdasarkan Undang-Undang, dengan tidak mendapatkan imbalan secara langsung dan digunakan untuk keperluan Daerah bagi sebesar-besarnya kemakmuran rakyat.

Berdasarkan kewenangan pemungutannya, di Indonesia pajak dapat dibagi menjadi Pajak Pusat dan Pajak Daerah. Menurut Panca didalam Sahara (2004:15) Pajak Daerah merupakan pajak yang dikelola oleh Pemerintah Daerah, baik Propinsi maupun Kabupaten atau Kota yang berguna untuk menunjang penerimaan Pendapatan Asli Daerah dan hasil penerimaan tersebut masuk dalam APBD.

\section{Administrasi Pajak Daerah}

Teori pembangunan dari bawah berpendapat bahwa orang akan lebih bersedia membayar pajak kepada daerah daripada kepada Pemerintah Pusat karena mereka dapat melihat manfaat dalam kemudahan dan pembangunan di daerah mereka. Meskipun demikian makin rendah tingkat pemerintahan daerah maka makin dekat antar mereka yang mengenakan pajak dengan mereka yang membayar pajak. Kebebasan untuk menentukan ruang lingkup, metode penilaian dan tarif pajak sendiri jelas akan mendorong kebebasan dan fleksibiltas dalam pembiayaan pemerintahan daerah. Tanggungjawab atas penilaian atau pemungutan suatu pajak atau retribusi tidak selalu bersamaan dengan kemudahan memperoleh hasilnya. Alokasi tanggungjawab untuk melakukan pengenaan dan pemungutan pajak tergantung pada sejumlah faktor : pertama ; tingkat kemampuan yang dibutuhkan dan tersedianya tenaga tersebut di tingkat daerah tertentu. Tenaga terampil mungkin terbatas dan sulit bagi pemerintah daerah untuk mempekerjakannya. Tiga faktor lainnya, kalau obyek dari setiap wajib pajak, khususnya suatu perusahaan melampaui batas-batas suatu daerah maka pengenaan secara terpusat mungkin diperlukan.

\section{Pengertian Pajak Hotel}

Sesuai dengan Undang - Undang Nomor 28 Tahun 2009 Pasal 1 angka 20 dan 21, Pajak Hotel adalah pajak atas pelayanan yang diadakan oleh Hotel. Sedangkan yang dimaksud dengan hotel adalah fasilitas penyedia jasa penginapan/peristirahatan termasuk jasa terkait lainnya dengan dipunggut bayaran, yang mencakup motel, losmen, gubuk pariwisata, wisma pariwisata, pesanggrahan, rumah 
penginapan dan sejensnya, serta rumah kos dengan jumlah besar lebih dari sepuluh. Pengenaan Pajak Hotel tidak mutlak ada pada seluruh kabupaten atau kota yang ada di Indonesia. Hal ini berkaitan dengan kewenangan yang diberikan kepada pemerintah kabupaten atau kota untuk mengenakan atau tidak mengenakan suatu jenis pajak kabupaten/kota. Oleh karena itu, untuk dapat dipungut suatu daerah kabupaten atau kota, pemerintah daerah harus terlebih dahulu menerbitkan peraturan daerah tentang Pajak Hotel. Peraturan itu akan menjadi landasan hukum operasional dalam teknis pelaksanaan pengenaan dan pemungutan Pajak Hotel di daerah kabupaten atau kota yang bersangkutan.

\section{Dasar Hukum Pemungutan Pajak Hotel}

Pemungutan Pajak Hotel Di Indonesia saat ini didasarkan pada dasar hukum yang jelas dan kuat, sehingga harus dipatuhi oleh masyarakat dan pihak terkait. Dasar hukum pemungutan Pajak Hotel pada suatu kabupaten atau kota diseluruh Indonesia yaitu Undang - Undang Nomor 28 Tahun 2009 tentang Pajak Daerah dan Retribusi Daerah. Dengan petunjuk teknis dari peraturan daerah masingmasing kabupaten kota.

\section{Penetapan Pajak Hotel}

a. Cara Pemungutan Pajak Hotel

Pemungutan Pajak Hotel tidak dapat diborongkan. Artinya, seluruh proses kegiatan pemungutan Pajak Hotel tidak dapat diserahkan kepada pihak ketiga. Walaupun demikian, dimungkinkan adanya kerja sama dengan pihak ketiga dalam proses pemungutan pajak, antara lain: pencetakan formulir perpajakan, pengiriman surat kepada wajib pajak, atau penghimpunan data objek pajak dan subjek pajak.

b. Penetapan Pajak Hotel

Setiap pengusaha hotel (yang menjadi wajib pajak) wajib menghitung, mempertimbangkan, membayar, dan melaporkan sendiri Pajak Hotel yang terutang dengan menggunakan SPTPD.

c. Ketetapan Pajak

Dalam jangka waktu 5 tahun sesudah saat terutangnya pajak, bupati/walikota dapat menerbitkan Surat Ketetapan Pajak Daerah Kurang Bayar (SKPDKB), Surat Ketetapan Pajak Daerah Kurang Bayar Tambahan (SKPDKBT), dan Surat Ketetapan Pajak Daerah Nihil (SKPDN).

d. Surat Tagihan Pajak Daerah (STPD)

Bupati/walikota dapat menerbitkan Surat Tagihan Pajak Daerah (STPD) jika Pajak Hotel dalam tahun berjalan tidak atau kurang dibayar; hassil penelitian SPTPD terdapat kekurangan pembayaran sebagai akiibat salah tulis atau salah hitung; dan wajib pajak dikenakan sanksi administrasi berupa bunga dan atau denda.

\section{Objek Pajak Hotel}

Objek Pajak Hotel adalah pelayanan yang disediakan oleh hotel dengan pembayaran, termasuk juga jasa penunjang sebagai kelengkapan hotel yang sifatnya memberikan kemudahan dan kenyamanan, termasuk fasilitas olahraga dan hiburan. Jasa penunjang sebagai kelengkapan hotel adalah fasilitas telepon, facsimile, teleks, internet, dan sejenis lainnya yang disediakan atau dikelola hotel, dalam pengenaan Pajak Hotel, yang menjadi objek pajak termasuk pelayanan yaitu,

1. Fasilitas penginapan atau fasilitas tinggal jangka pendek, dalam pengertian rumah penginapan rumah penginapan termasuk rumah kos dengan jumlah kamar sepuluh atau lebih yang menyediakan fasilitas seperti rumah penginapan.

2. Pelayanan penunjang sebagai kelengkapan fasilitas penginapan atau tempat tinggal jangka pendek yang sifatnya memberikan kemudahan dan kenyamanan.

3. Fasilitas olahraga dan hiburan yang disediakan khusus untuk tamu hotel.

4. Jasa persewaan ruangan untuk kegiatan acara atau pertemuan di hotel.

\section{Subjek Pajak dan Wajib Pajak Hotel}

Pajak hotel yang menjadi subjek pajak adalah orang pribadi atau badan yang melakukan pembayaran kepada orang pribadi atau badan yang mengusahakan hotel. Secara sederhana yang menjadi subjek pajak adalah konsumen yang menikmati dan membayar pelayanan yang diberikan pengusaha hotel. Sedangkan yang menjadi wajib pajak adalah orang pribadi atau badan dalam bentuk apa pun yang dalam lingkungan perusahaan atau pekerjaannya melakukan usaha dibidang jasa penginapan. Dengan demikian, pada Pajak Hotel subjek pajak dan wajib pajak tidak sama, dimana konsumen yang menikmati pelayanan hotel merupakan subjek pajak yang membayar (menanggung) pajak sementara orang pribadi atau badan yang mengusahakn hotel bertindak sebagai wajib pajak yang diberi kewenangan untuk memungut pajak dari konsumen (subjek pajak) dan melaksanakan kewajiban perpajakan lainnya. Dalam menjalankan kewajiban perpajakan wajib pajak dapat diwakili oleh pihak tertentu yang diperkenankan oleh undang - undang dan peraturan daerah tentang Pajak Hotel. Wakil wajib pajak bertanggung jawab secara pribadi dan atau secara langsung renteng atas pembayaran pajak terutang. Selain itu, wajib pajak dapat menunjuk seorang kuasa dan surat kuasa khusus untuk menjalankan hak dan kewajiban perpajaknnya.

\section{Pengertian Pajak Restoran}

Sesuai dengan undang-undang Nomor 28 Tahun 2009 pasal 1 angka 22 dan 23, pajak restoran adalah pajak atas pelayanan yang di sediakan oleh restoran. Sedangkan yang di maksud dengan restoran adalah fasilitas penyedia makanan dan atau minuman dengan di pungut bayaran, yang mencakup juga rumah makan, kafetaria, kantin, warung, bar dan sejenisnya termasuk jasa boga/catering. Pemungutan pajak restoran di Indonesia saat ini di dasarkan pada undang-undang Nomor 34 Tahun 1997 tentang pajak daerah dan retribusi daerah dan peraturan pemerintah Nomor 65 Tahun 2001 tentang pajak daerah.

Tahun 1997 pajak atas restoran di samakan dengan restoran dengan nama pajak hotel dan restoran. Tetapi berdasarkan undang-undang Nomor 34 Tahun 2000 jenis pajak tersebut di pisahkan menjadi dua jenis pajak yang berdiri sendiri, yaitu pajak hotel dan pajak restoran. 
Keberadaan pajak restoran sebagai salah satu jenis pajak kabupaten/kota di atur juga dalam undang-undang Nomor 28 Tahun 2009, yang mulai berlaku tanggal 1 januari 2010 menjadi dasar hukum pajak daerah di Indonesia.

\section{Objek pajak restoran}

Objek pajak restoran adalah pelayanan yang di sediakan oleh restoran. Pelayanan yang di sediakan restoran meliputi pelayanan penjualan makanan dan atau minuman yang di konsumsi oleh pembeli, baik di konsumsi di tempat pelayanan maupun di tempat lain. Termasuk dalam objek pajak restoran adalah rumah makan, café, bar, dan sejenisnya. Dalam undang-undang Nomor 28 Tahun 2009 pasal 37 ayat 3 di sebutkan bahwa yang tidak termasuk objek pajak restoran adalah pelayanan yang di sediakan oleh restoran yang nilai penjualannya tidak melebihi batas tertentu yang di tetapkan dengan peraturan daerah.

\section{Subjek pajak dan Wajib pajak restoran}

Subjek pajak adalah orang pribadi atau badan yang membeli makanan dan atau minuman dari restoran, secara sederhana yang menjadi subjek pajak adalah konsumen yang membeli makanan dan atau minuman dari restoran, sedangkan yang menjadi wajib pajak adalah orang pribadi atau badan dalam bentuk apa pun yang dalam lingkungan perusahaan atau pekerjaannya melakukan usaha di bidang rumah makan.

\section{Tariff pajak restoran}

Tarif pajak restoran di tetapkan paling tinggi sebesar $10 \%$ dan di tetapkan dengan peraturan daerah kabupaten/kota yang bersangkutan.

\section{Perhitungan dan pemungutan pajak restoran}

Pajak terutang $=$ tarif pajak $\mathrm{x}$ dasar pengenaan pajak

= tarif pajak $\mathrm{x}$ jumlah pembayaran yang di terima atau yang seharusnya di terima restoran.

Pemungutan pajak restoran tidak dapat di borongkan, artinya seluruh proses kegiatan pemungutan pajak restoran tidak dapat di serahkan kepada pihak ketiga, walaupun demikian, di mungkinkan adanya kerja sama dengan pihak ketiga dalam proses pemungutan pajak, antara lain pencetakan formulir perpajakan, pengiriman surat-surat kepada wajib pajak atau penghimpun data objek dan subjek pajak. Setiap pengusaha restoran ( yang menjadi wajib pajak ) wajib menhitung, memperhitungkan, membayar, dan melaporkan sendiri pajak restoran yang terutang dengan menggunakan SPTPD. Ketentuan ini menunjukan system self assessment, yaitu wajib pajak di beri kepercayaan penuh untuk menghitung, memperhitungkan, membayar dan melaporkan sendiri pajak yang terutang.

\section{Pengertian Pendapatan Asli Daerah (PAD)}

Pendapatan Asli Daerah (PAD) adalah penerimaan yang diperoleh daerah dari sumber-sumber dalam wilayahnya sendiri yang dipungut berdasarkan peraturan daerah sesuai dengan peraturan perundang-undangan yang berlaku (Dalam buku Marihot.P.Siahaan:2005, hal 14). Kemudian Pendapatan Asli Daerah (PAD) yaitu pendapatan yang diperoleh daerah dan dipungut berdasarkan peraturan daerah sesuai dengan peraturan perundang-undangan (Dalam buku Marihot.P.Siahaan:2005, hal 15).

\section{Pajak Daerah}

Secara umum Pajak (Marihot.P.Siahaan,2005:hal 7) adalah pungutan dari masyarakat oleh Negara (Pemerintah) berdasarkan undang-undang yang bersifat dapat dipaksakan dan terutang oleh yang wajib membayarnya dengan tidak mendapat prestasi kembali (kontra prestasi/balas jasa) secara langsung, yang hasilnya digunakan untuk membiayai pengeluaran Negara dalam penyelenggaraan pemerintahan dan pembangunan.

\section{Retribusi Daerah}

Retribusi (Marihot. P.Siahaan, 2005: hal 5) adalah pembayaran wajib dari penduduk kepada Negara karena adanya jasa tertentu yang diberikan oleh Negara bagi penduduknya secara perorangan. Pengertian retribusi secara umum adalah pembayaranpembayaran kepada Negara yang dilakukan oleh mereka yang menggunakan jasa-jasa Negara. Retribusi daerah yang selanjutnya disebut Retribusi (Marihot.P.Siahaan,2005:hal 432) adalah pungutan daerah sebagai pembayaran atas jasa atau pemberian izin tertentu yang khusus disediakan dan atau diberikan oleh pemerintah daerah untuk kepentingan orang pribadi atau badan.

\section{Lain-lain PAD yang sah}

Lain-lain pendapatan asli daerah yang sah meliputi yaitu:

1) Hasil penjualan kekayaan daerah yang tidak dipisahkan;

2) Jasa giro;

3) Pendapatan bunga;

4) Keuntungan selisih nilai tukar rupiah terhadap mata uang asing;

5) Komisi, potongan, ataupun bentuk lain sebagai akibat dari penjualan dan/ atau pengadaan barang dan/ atau jasa oleh daerah.

6) Penerimaan atas tuntutan ganti kerugian daerah;

7) Pendapatan denda atas keterlambatan pelaksanaan pekerjaan;

8) Pendapatan denda pajak;

9) Pendapatan denda retribusi;

10) Pendapatan hasil eksekusi atas jaminan;

11) Pendapatan dari pengembalian;

12) Fasilitas social dan fasilitas umum;

13) Pendapatan dari penyelenggaraan pendidikan dan pelatihan;dan

14) Pendapatan dari angsuran/cicilan penjualan.

\section{METODE PENELITIAN \\ Pendekatan Penelitian}

Pendekatan penelitian yang digunakan dalam penelitian ini adalah pendekatan kuantitatif yaitu pengukuran data kuantitatif dan statistik objektif melalui perhitungan ilmiah, dalam metode penelitian kuantitatif, masalah yang diteliti lebih umum memiliki wilayah yang luas, tingkat variasi yang kompleks, serta penelitian kuantitatif lebih sistematis, terencana, terstruktur, jelas dari awal hingga akhir penelitian atau dengan kata lain Metode penelitian kuantitatif merupakan salah satu jenis penelitian yang spesifikasinya adalah sistematis, terencana, dan terstruktur dengan jelas sejak awal hingga pembuatan desain penelitiannya. Definisi lain menyebutkan penelitian 
kuantitatif adalah penelitian yang banyak menuntut penggunaan angka, mulai dari pengumpulan data, penafsiran terhadap data tersebut, serta penampilan dari hasilnya. Demikian pula pada tahap kesimpulan penelitian akan lebih baik bila disertai dengan gambar, table, grafik, atau tampilan lainnya.

\section{Metode Analisis Data}

Pembahasan mengenai pengeluaran pendapatan asli daerah Kabupaten Jayapura, menggunakan metode analisis sebagai berikut :

a) Pengaruh variabel $\mathrm{X}_{1}, \mathrm{X}_{2}$, terhadap $\left(\mathrm{Y}_{2}\right)$ pendapatan asli daerah melalui pajak daerah $\left(\mathrm{Y}_{1}\right)$. Untuk memenuhi tujuan penelitian serta menguji hipotesis yang telah ditetapkan maka analisis yang digunakan adalah regresi berganda dengan metode Structural Equation Modeling (SEM). Metode ini mempunyai keunggulan yaitu secara teknis sangat akurat, mudah dalam menginterprestasikan perhitungannya serta sebagai alat estimasi linier maupun non-linier Sumber : Halim, Akuntansi Keuangan Daerah, 2007. Regresi dilakukan terhadap model persamaan regresi yang diturunkan adalah sebagai berikut :

$$
\begin{aligned}
& \mathrm{Y}_{1}=f\left(\mathrm{X}_{1}, \mathrm{X}_{2}\right) \\
& \mathrm{Y}_{2}=f\left(\mathrm{X}_{1}, \mathrm{X}_{2}, \mathrm{Y}_{1}\right)
\end{aligned}
$$

Selanjutnya untuk menyesuaikan dengan penelitian ini diasumsikan bahwa $\mathrm{Y}$ adalah pendapatan asli daerah yang merupakan variabel dependen, sedangkan $\mathrm{X}$ adalah variabel independen yang terdiri dari pajak hotel $\left(\mathrm{X}_{1}\right)$, pajak restoran $\left(\mathrm{X}_{2}\right)$, dan sedangkan model yang digunakan dengan modifikasi dalam bentuk Structural Equation Modeling (SEM) sebagai berikut :

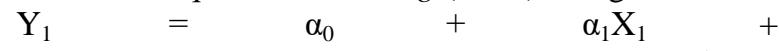

Berdasarkan hasil penelitian yang telah dilaksanakan oleh peneliti dengan komposisi data penelitian dari tahun 2015 - 2019 dimana akan diuraikan data penerimaan pajak hotel, pajak restoran dan pajak daerah seperti pada tabel-tabel berikut :

Perkembangan Realisasi Pajak Hotel dan Pajak Restoran Tahun 2015-2019

\begin{tabular}{|l|l|l|l|}
\hline No & Tahun & Pajak Hotel & Perkembangan \\
\hline 1 & 2015 & 1.766 .120 .244 & - \\
\hline 2 & 2016 & 1.387 .622 .339 & $(21,43)$ \\
\hline 3 & 2017 & 1.620 .573 .747 & 16,79 \\
\hline 4 & 2018 & 2.485 .774 .912 & 53,39 \\
\hline 5 & 2019 & 2.115 .239 .744 & $(14,91)$ \\
\hline \multicolumn{2}{|l}{ Rerata } & 6,77 \\
\hline
\end{tabular}

Sumber : data diolah, 2020

Berdasarkan tabel diatas dapat dijelaskan bahwa penerimaan pajak hotel tahun 2016 mengalami penurunan sebesar 21.43 persen dibandingkan dengan tahun sebelumnya, tahun 2017 mengalami peningkatan sebesar 16,79 persen dan tahun 2018 terus mengalami peningkatan sebesar 53,39 persen akan tetapi tahun 2019 mengalami penurunan sebesar 14,91 persen, ini sebagai dampak dari adanya bencana alam yaitu banjir bandang yang melanda daerah Sentani dan sekitarnya. Dan rata-rata peningkatan penerimaan pajak hotel setiap tahunnya sebesar 6,77 persen. Dan berikut adalah perkembangan penerimaan pajak restoran sebagai berikut :

Perkembangan Pajak Restoran

Tahun 2015-2019

\begin{tabular}{|l|l|l|l|}
\hline No & Tahun & Pajak Restoran & Perkembangan (\%) \\
\hline 1 & 2015 & 2.928 .814 .380 & - \\
\hline 2 & 2016 & 3.516 .416 .868 & 20,06 \\
\hline 3 & 2017 & 4.268 .410 .519 & 21,39 \\
\hline 4 & 2018 & 5.421 .066 .816 & 27,00 \\
\hline 5 & 2019 & 8.023 .858 .480 & 48,01 \\
\hline \multicolumn{2}{|l}{ Rerata } & 23,29 \\
\hline
\end{tabular}

Sumber : data diolah, 2020

Berdasarakan tabel diatas dapat dijelaskan

bahwa perkembangan penerimaan pajak restoran mengalami peningkatan dimana peningkatan terbesar terjadi pada tahun 2019 sebesar 48,01 persen dan yang 
terendah tahun 2016 sebesar 20,06 persen. Dan perkembangan pajak daerah seperti pada tabel berikut Perkembangan Pajak Daerah

Tahun 2015-2019

\begin{tabular}{|l|l|l|l|}
\hline No & Tahun & Pajak Daerah & $\%$ \\
\hline 1 & 2015 & $20.437 .426 .648,75$ & - \\
\hline 2 & 2016 & $27.171 .795 .078,13$ & 32,95 \\
\hline 3 & 2017 & $35.672 .561 .883,22$ & 31,29 \\
\hline 4 & 2018 & $38.851 .922 .230,00$ & 8,91 \\
\hline 5 & 2019 & $38.880 .544 .591,90$ & 0,07 \\
\hline \multicolumn{2}{|l}{ Rata-rata } & 14,64 \\
\hline
\end{tabular}

Sumber : data diolah, 2020

Berdasarkan tabel diatas dapat dijelaskan bahwa tren perkembangan pajak daerah terus mengalami peningkatan, dimana peningkatan terbesat terjadi pada tahun 2016 yaitu sebesar 32,95 persen, dan peningkatan terendah tahun 2019 yaitu sebesar 0,07 persen dari tahun sebelumnya, dan rata-rata peningkatan setiap tahun sebesar 14,64 persen. Dan berikut adalah penerimaan pendapatan asli daerah seperti pada tabel berikut

Perkembangan Penerimaan Pendapatan Asli Daerah

Tahun 2015-2019

\begin{tabular}{|l|l|l|l|}
\hline No & Tahun & PAD & $\%$ \\
\hline 1 & 2015 & 74.130 .385 .459 & - \\
\hline 2 & 2016 & 87.394 .171 .637 & 17,89 \\
\hline 3 & 2017 & 96.961 .324 .537 & 10,95 \\
\hline 4 & 2018 & 88.771 .869 .296 & $-8,45$ \\
\hline 5 & 2019 & 103.441 .919 .381 & 16,53 \\
\hline \multicolumn{2}{|l|}{ Rata-rata } & 7,38 \\
\hline
\end{tabular}

Sumber : data diolah, 2020

Berdasarkan tabel diatas dapat dijelaskan bahwa peningkatan perkembangan pendapatan asli daerah berfluktuatif dimana perkembangan terbesar terjadi pada tahun 2016 sebesar 17,89 persen dan terendah pada tahun 2018 sebesar 8,45 persen. Dan berikut rekapitukasi .datadata penelitian seperti pada tabel berikut :

Rekapitulasi data Penelitian

\begin{tabular}{|l|l|l|l|l|}
\hline Tahun & Pajak Hotel & $\begin{array}{l}\text { Pajak } \\
\text { Restoran }\end{array}$ & Pajak Daerah & Pendapatan Asli Daerah \\
\hline 2015 & $1.766 .120 .244,25$ & 2.928 .814 .380 & $20.437 .426 .648,75$ & $74.130 .385 .458,92$ \\
\hline 2016 & $1.387 .622 .339,00$ & 3.516 .416 .868 & $27.171 .795 .078,13$ & $87.394 .171 .637,46$ \\
\hline 2017 & $1.620 .573 .746,80$ & 4.268 .410 .519 & $35.672 .561 .883,22$ & $96.961 .324 .536,63$ \\
\hline 2018 & $2.485 .774 .911,80$ & 5.421 .066 .816 & $38.851 .922 .230,00$ & $88.771 .869 .296,37$ \\
\hline 2019 & $2.115 .239 .744,00$ & 8.023 .858 .480 & $38.880 .544 .591,90$ & $103.441 .919 .381,47$ \\
\hline
\end{tabular}

\section{Pembahasan}

Sumber : Data diolah, 2020

Berdasarkan hasil pengolahan regresi pertama dan pengolahan regresi kedua dan selanjutnya dilakukan pengukuran mengenai pengaruh langsung dan pengaruh tidak langsung variabel pajak hotel dan pajak restoran terhadap terhadap pendapatan asli daerah melalui pajak daerah pada tabel berikut.

Hasil Estimasi Pengaruh Langsung dan Pengaruh Tidak Langsung

\begin{tabular}{|l|l|l|l|}
\hline Hubungan & Pengaruh Langsung & $\begin{array}{l}\text { Pengaruh Tidak } \\
\text { Langsung }\end{array}$ & $\begin{array}{l}\text { Pengaruh } \\
\text { Total }\end{array}$ \\
\hline X1 ke Y1 & 3,59 & - & 3,59 \\
\hline X2 ke Y1 & 2,76 & - & 2,76 \\
\hline X1 ke Y2 & 15,93 & $3,59 \times 1,05=3,77$ & 19,70 \\
\hline X2 ke Y2 & 3,14 & $2,76 \times 1,05=2,90$ & 9,10 \\
\hline Y1 ke Y2 & 1,05 & - & 1,05 \\
\hline
\end{tabular}




\section{Pengaruh Pajak Hotel Terhadap Pendapatan Asli Daerah Melalui Pajak Daerah.}

Menurut Undang-undang Republik Indonesia Nomor 28 Tahun 2009 tentang Pajak Daerah bahwa Pajak Hotel adalah pajak atas pelayanan yang disediakan oleh hotel. Hotel adalah fasilitas penyedia jasa penginapan/peristirahatan termasuk jasa terkait lainnya dengan dipungut bayaran, yang mencakup juga hotel, losmen, gubuk pariwisata, wisma pariwisata, pesanggrahan, rumah penginapan dan sejenisnya, serta rumah kos dengan jumlah kamar lebih dari 10 (sepuluh).

Berdasarkan hasil olah data yang telah dilakukan didapatkan nilai pengaruh langsung pajak hotel terhadap pendapatan asli daerah adalah sebesar 15,53 dan pengaruh tidak langsung sebesar 3,77 yang berarti bahwa nilai pengaruh tidak langsung lebih kecil dari pengaruh langsung, hasil ini menunjukkan bahwa pajak hotel mampu memediasi pengaruh pajak hotel terhadap perkembangan penerimaan pendapatan asli daerah di Kabupaten Jayapura. Penerimaan pajak hotel mampu memberikan kontribusi bagi peningkatan penerimaan pajak daerah dan berujung pada juag pada penignkatan pendapatan asli daerah. Untuk meningkatkan pendapatan asli daerah, pemerintah kabupaten Jayapura harus bisa menggali sumbersumber yang dapat menghasilkan pendapatan di wilayahnya yang berpotensi untuk dipungut pajak. Pajak pajak hotel termasuk dalam sumber pajak daerah yang potensial dalam memberikan pemasukan bagi kas daerah dan kontribusi yang diberikan dapat memacu pembangunan ekonomi di Kabupaten Jayapura.

\section{Pengaruh Pajak Restoran Terhadap Pendapatan Asli Daerah Melalui Pajak Daerah.}

Menurut Undang-undang Nomor 28 Tahun 2009 tentang pajak daerah dan retribusi daerah (UU Pajak Daerah). Pengertian pajak restoran adalah pajak atas pelayanan yang disediakan oleh restoran. Lebih lanjut disebutkan bahwa restoran adalah fasilitas penyedia makanan atau minuman dengan dipungut bayaran, yang mencakup juga rumah makan, cafeteria, kantin, warung, bar, dan sejenisnya termasuk jasa boga atau catering.

Berdasarkan hasil olah data yang telah dilakukan didapatkan nilai pengaruh langsung pajak restoran terhadap pendapatan asli daerah adalah sebesar 3,14 dan pengaruh tidak langsung sebesar 2,90 yang berarti bahwa nilai pengaruh tidak langsung lebih kecil dari pengaruh langsung, hasil ini menunjukkan bahwa pajak restoran mampu memediasi pengaruh pajak restoran terhadap perkembangan penerimaan pendapatan asli daerah di Kabupaten Jayapura. Penerimaan pajak restoran mampu memberikan kontribusi bagi peningkatan penerimaan pajak daerah dan berujung pada juga pada peningkatan pendapatan asli daerah. Untuk meningkatkan pendapatan asli daerah, pemerintah kabupaten Jayapura harus bisa menggali sumber-sumber yang dapat menghasilkan pendapatan di wilayahnya yang berpotensi untuk dipungut pajak. Selain pajak hotel pajak restoran termasuk dalam sumber pajak daerah yang potensial dalam memberikan pemasukan bagi kas daerah dan kontribusi yang diberikan dapat memacu pembangunan ekonomi di Kabupaten Jayapura.

\section{Pengaruh Langsung (Direct Effek)}

Dapat dijelaskan bahwa, apabila pajak hotel $\left(\mathrm{X}_{1}\right)$, meningkat sebesar 1 persen akan berpengaruh terhadap peningkatan pajak daerah $\left(\mathrm{Y}_{1}\right)$ sebesar 3,59 persen dengan $\alpha=0,501$ atau diatas 0,05 yang artinya pengaruh pajak hotel terhadap pajak daerah $\left(\mathrm{Y}_{1}\right)$ tidak signifikan.

Pengaruh variabel pajak hotel $\left(\mathrm{X}_{1}\right)$, terhadap pendapatan asli daerah, apabila pajak hotel $\left(\mathrm{X}_{1}\right)$ meningkat sebesar 1 persen akan berpengaruh terhadap peningkatan pendapatan asli daerah $\left(\mathrm{Y}_{2}\right)$ sebesar 15,93 persen dengan $\alpha=0,037$ atau dibawah 0,05 yang artinya pengaruh pajak hotel terhadap pendapatan asli daerah $\left(\mathrm{Y}_{2}\right)$ signifikan.

Pengaruh variabel pajak restoran $\left(\mathrm{X}_{2}\right)$ terhadap pajak daerah $\left(\mathrm{Y}_{1}\right)$, apabila pajak hotel naik sebesar 1 persen akan berpengaruh terhadap peningkatan pajak daerah sebesar $\left(\mathrm{Y}_{1}\right)$ sebesar 2,76 persen dengan tingkat signifikansi 0,32 atau diatas 0,05 yang artinya bahwa pengaruh pajak hotel terhadap pajak daerah $\left(\mathrm{Y}_{1}\right)$ tidak signifikan.

Tabel diatas juga menjelaskan bahwa pengaruh langsung antar variabel, dimana apabila pajak hotel $\left(\mathrm{X}_{2}\right)$ meningkat sebesar 1 persen akan berpengaruh terhadap peningkatan pendapatan asli daerah $\left(\mathrm{Y}_{2}\right)$ sebesar 3,14 persen dengan tingkat signifikansi 0,096 atau diatas 0,05 yang artinya pengaruh pajak hotel terhadap pendapatan asli daerah tidak signifikan.

Pengaruh pajak daerah $\left(\mathrm{Y}_{1}\right)$ terhadap pendapatan asli daerah $\left(\mathrm{Y}_{2}\right)$ adalah sebesar 1,05 dengan tingkat signifikansi 0.102 atau lebih besar dari 0,05 yang berarti tidak signifikan artinya bahwa ada hubungan antara pajak daerah dengan pendapatan asli daerah akan tetapi hubungannya tidak signifikan, dalam artian bahwa masih ada komponen lain yang mempengaruhi peningkatan penerimaan pendapatan asli daerah di Kabupaten Jayapura.

Pengaruh pajak daerah $\left(\mathrm{Y}_{2}\right)$ terhadap pendapatan asli daerah $\left(\mathrm{Y}_{3}\right)$ adalah 1,05 dengan tingkat signifikansi 0,102 atau lebih besar dari 0,05 yang berarti tidak signifikan artinya bahwa ada hubungan antara pajak daerah dengan pendapatan asli daerah tapi tidak signifikan, hal ini searah dengan hepotesis dalam penelitian ini..

\section{Pengaruh tidak Langsung (Indirect Effect)}

Pengaruh tidak langsung antar masingmasing variabel bebas dengan variabel terikat, berdasarkan hasil output metode SPSS dapat diuraikan 
pengaruh tidak langsung masing-masing variabel, dimana pengaruh pajak hotel $\left(\mathrm{X}_{1}\right)$ terhadap pendapatan alsi daerah $\left(\mathrm{Y}_{3}\right)$ melalui pajak daerah $\left(\mathrm{Y}_{1}\right)$ sebesar 3,77 artinya apabila jumlah penerimaan pajak hotel naik maka pendapatan asli daerah $\left(\mathrm{Y}_{2}\right)$ juga naik. Sedangkan pengaruh pajak restoran $\left(\mathrm{X}_{2}\right)$ terhadap pendapatan asli daerah $\left(\mathrm{Y}_{2}\right)$ melalui melalui pajak daerah $\left(\mathrm{Y}_{1}\right)$ sebesar 2,90 artinya apabila pajak restoran $\left(\mathrm{X}_{2}\right)$ naik maka pendapatan asli daerah $\left(\mathrm{Y}_{2}\right)$ juga mengalami kenaikan.

5. Pengaruh Total (Total Effect).

Pengaruh total adalah pengaruh secara keseluruhan antara pengaruh langsung dan pengaruh tidak langsung pada masing-masing variabel eksogen yaitu pajak hotel $\left(\mathrm{X}_{1}\right)$, pajak restoran $\left(\mathrm{X}_{2}\right)$ melalui pajak daerah $\left(\mathrm{Y}_{1}\right)$ terhadap pendapatan asli daerah $\left(\mathrm{Y}_{2}\right)$, untuk melihat pengaruh total masing-masing variabel eksogen terhadap masing-masing fungsi pajak daerah $\left(\mathrm{Y}_{1}\right)$ serta pendapatan asli daerah $\left(\mathrm{Y}_{2}\right)$, seperti pada tabel 4.8 .

Pengujian hipotesis dalam penelitian ini dilakukan dengan uji statistik pada masing-masing jalur pengaruh langsung secara parsial, hasil analisis secara lengkap terdapat dalam analisis SPSS, dapat dilihat pada lampiran penelitian ini, sedangkan ringkasan hasil pengujian hipotesis yang diperoleh dari lampiran dapat dilihat pada tabel berikut

Ringkasan Hasil Pengujian Hipotesis

\begin{tabular}{|l|l|l|l|}
\hline Hubungan & Pengaruh Langsung & $\begin{array}{l}\text { Pengaruh Tidak } \\
\text { Langsung }\end{array}$ & Pengaruh Total \\
\hline X1 ke Y1 & 3,59 & - & 3,59 \\
\hline X2 ke Y1 & 2,76 & - & 2,76 \\
\hline X1 ke Y2 & 15,93 & $\begin{array}{l}3,59 \times 1,05= \\
3,77\end{array}$ & 19,70 \\
\hline X2 ke Y2 & 3,14 & $\begin{array}{l}2,76 \times 1,05= \\
2,90\end{array}$ & 9,10 \\
\hline Y1 ke Y2 & 1,05 & - & 1,05 \\
\hline
\end{tabular}

Sumber ; lampiran 2, data diolah, 2020

Dari dua variabel eksogen yang dihipotesiskan mempengaruhi pendapatan asli daerah $\left(\mathrm{Y}_{2}\right)$ melalui pajak daerah $\left(\mathrm{Y}_{1}\right)$ yaitu pajak hotel $\left(\mathrm{X}_{1}\right)$, pajak restoran $\left(\mathrm{X}_{2}\right)$ dimana keduanya tidak signifikan terhadap pajak daerah $\left(\mathrm{Y}_{1}\right)$, sedangkan pengaruh pajak hotel $\left(\mathrm{X}_{1}\right)$, pajak restoran $\left(\mathrm{X}_{2}\right)$ terhadap pendapatan asli daerah $\left(\mathrm{Y}_{2}\right)$ dimana variabel antara tersebut tidak signifikan.

\section{Kesimpulan}

1. Hasil analisis didapatkan bahwa apabila pajak hotel $\left(\mathrm{X}_{1}\right)$, meningkat sebesar 1 persen akan berpengaruh terhadap peningkatan pajak daerah $\left(\mathrm{Y}_{1}\right)$ sebesar 3,59 persen dengan $\alpha=0,501$ atau diatas 0,05 yang artinya pengaruh pajak hotel terhadap pajak daerah $\left(\mathrm{Y}_{1}\right)$ tidak signifikan. Pengaruh variabel pajak hotel $\left(\mathrm{X}_{1}\right)$, terhadap pendapatan asli daerah, apabila pajak hotel $\left(\mathrm{X}_{1}\right)$ meningkat sebesar 1 persen akan berpengaruh terhadap peningkatan pendapatan asli daerah $\left(\mathrm{Y}_{2}\right)$ sebesar 15,93 persen dengan $\alpha=0,037$ atau dibawah 0,05 yang artinya pengaruh pajak hotel terhadap pendapatan asli daerah $\left(\mathrm{Y}_{2}\right)$ signifikan. Pengaruh variabel pajak restoran $\left(\mathrm{X}_{2}\right)$ terhadap pajak daerah $\left(\mathrm{Y}_{1}\right)$, apabila pajak hotel naik sebesar 1 persen akan berpengaruh terhadap peningkatan pajak daerah sebesar $\left(\mathrm{Y}_{1}\right)$ sebesar 2,76 persen dengan tingkat signifikansi 0,32 atau diatas 0,05 yang artinya bahwa pengaruh pajak hotel terhadap pajak daerah $\left(\mathrm{Y}_{1}\right)$ tidak signifikan. pembahasan diatas juga menjelaskan bahwa pengaruh langsung antar variabel, dimana apabila pajak hotel $\left(\mathrm{X}_{2}\right)$ meningkat sebesar 1 persen akan berpengaruh terhadap peningkatan pendapatan asli daerah $\left(\mathrm{Y}_{2}\right)$ sebesar 3,14 persen dengan tingkat signifikansi 0,096 atau diatas 0,05 yang artinya pengaruh pajak hotel terhadap pendapatan asli daerah tidak signifikan. Pengaruh pajak daerah $\left(\mathrm{Y}_{1}\right)$ terhadap pendapatan asli daerah $\left(\mathrm{Y}_{2}\right)$ adalah sebesar 1,05 dengan tingkat signifikansi 0.102 atau lebih besar dari 0,05 yang berarti tidak signifikan artinya bahwa ada hubungan antara pajak daerah dengan pendapatan asli daerah akan tetapi hubungannya tidak signifikan, dalam artian bahwa masih ada komponen lain yang mempengaruhi peningkatan penerimaan pendapatan asli daerah di Kabupaten Jayapura. Pengaruh pajak daerah $\left(\mathrm{Y}_{2}\right)$ terhadap pendapatan asli daerah $\left(\mathrm{Y}_{3}\right)$ adalah 1,05 dengan tingkat signifikansi 0,102 atau lebih besar dari 0,05 yang berarti tidak signifikan artinya bahwa ada hubungan antara pajak daerah dengan pendapatan asli daerah tapi tidak signifikan, hal ini searah dengan hepotesis dalam penelitian ini..

2. Pengaruh tidak langsung antar masing-masing variabel bebas dengan variabel terikat, berdasarkan hasil output metode SPSS dapat diuraikan pengaruh tidak langsung masing-masing variabel, dimana pengaruh pajak hotel $\left(\mathrm{X}_{1}\right)$ terhadap pendapatan alsi daerah $\left(\mathrm{Y}_{3}\right)$ melalui pajak daerah $\left(\mathrm{Y}_{1}\right)$ sebesar 3,77 artinya apabila jumlah penerimaan pajak hotel naik maka pendapatan asli daerah $\left(\mathrm{Y}_{2}\right)$ juga naik. Sedangkan pengaruh pajak restoran $\left(\mathrm{X}_{2}\right)$ terhadap pendapatan asli daerah $\left(\mathrm{Y}_{2}\right)$ melalui melalui pajak daerah $\left(\mathrm{Y}_{1}\right)$ sebesar 2,90 artinya apabila pajak restoran $\left(\mathrm{X}_{2}\right)$ naik maka pendapatan asli daerah $\left(\mathrm{Y}_{2}\right)$ juga mengalami kenaikan. 
3. Pengaruh total adalah pengaruh secara keseluruhan antara pengaruh langsung dan pengaruh tidak langsung pada masing-masing variabel eksogen yaitu pajak hotel $\left(\mathrm{X}_{1}\right)$, pajak restoran $\left(\mathrm{X}_{2}\right)$ melalui pajak daerah $\left(\mathrm{Y}_{1}\right)$ terhadap pendapatan asli daerah $\left(\mathrm{Y}_{2}\right)$, untuk melihat pengaruh total masing-masing variabel eksogen terhadap masing-masing fungsi pajak daerah $\left(\mathrm{Y}_{1}\right)$ serta pendapatan asli daerah $\left(\mathrm{Y}_{2}\right)$..

\section{DAFTAR PUSTAKA}

Ghozali, I. 2011. Aplikasi Analisis Multivariate dengan Program IBM SPSS 19. Semarang:Badan Penerbit-UNDIP.

Kuncoro, W. 2011. Kontribusi Bidang Pariwisata terhadap Peningkatan Pendapatan Asli Daerah (Studi tentang Pajak Hotel, Pajak Restoran dan Pajak Hiburan di Kota Batu). Malang: Universitas Brawijaya.

Mahmudi. 2010. Manajemen Keuangan Daerah. Yogyakarta: Penerbit Erlangga.

Priyatno, D. 2012. Cara Kilat Belajar Analisis Data dengan SPSS 20. Yogyakarta: ANDI.

Putri, E. 2011. Pengaruh Pajak Hotel dan Pajak Restoran dalam rangka meningkatkan Pendapatan Asli Daerah Kabupaten Sidoarjo. Malang: Universitas Brawijaya.

Ruswandi, R. 2009. Analisis Pengaruh Pajak Daerah terhadap Pendapatan Asli Daerah di Kabupaten Sumedang. Bogor: Institut Pertanian Bogor.

Suryantoro, H. 2011. Pengaruh Pajak Daerah terhadap Pendapatan Asli Daerah Kabupaten Tulungagung. Malang: Univeritas Brawijaya

\section{Undang-Undang :}

Undang-Undang No.33. 388_ Tentang Perimbangan Keuangan antara Pemerintah Pusat dan Pemerintahan Daerah No.33 Tahun 2013 dari www.djlpe.esdm.go.id

Undang-Undang No: 88_ Tentang Perubahan Ketiga Undang-undang Nomor 6 Tahun 1983 Tentang Ketentuan Umum dan Tata Cara Perpajakan diakses pada Tanggal 28 November 2019 dari jdih.bpk.go.id

Undang-Undang No 88 Tentang Pajak Daerah dan Retribusi Daerah No.28 Tahun 2013 dari bppt.provpapua.go.id 